総説

\title{
油脂の水素添加
}

\author{
高橋 喜和*1 $\cdot$ 依田稔*2 \\ ミョシ油脂株式会社 \\ （于124-8510 東京都葛飾区堀切 4-66-1） \\ $* 1$ 生産本部 \\ $* 2$ 食品事業本部 技術部
}

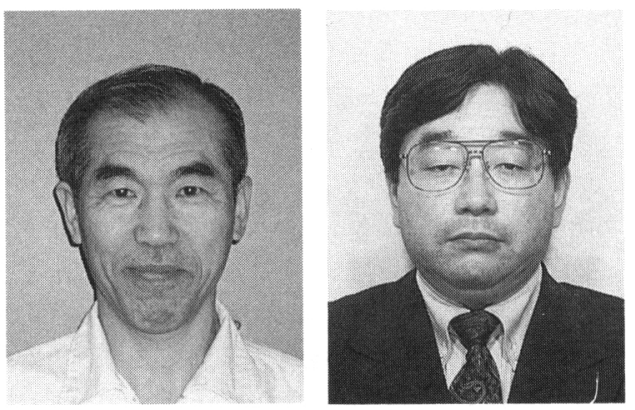

\section{Hydrogenation of Edible Oil}

\author{
Yoshikazu TAKAHASHI ${ }^{* 1}$ and Minoru YODA ${ }^{* 2}$ \\ Miyoshi Oil \& Fat Co., Ltd. (4-66-1, Horikiri, Katsushika-ku, Tokyo 124-8510) \\ * 1 Production Division \\ *2 Food Division, Reseach \& Development Section
}

\begin{abstract}
The hydrogenation of edible oil is a basic means for converting liquid oils into plastic fats at oil and fat companies.

Fundamental hydrogenation and current continuous reactor using a fixed-bed catalyst and supercritical process are discussed. New types of nickel and precious metal catalysts and current developments in reactors are presented.
\end{abstract}

Key words : hydrogenation, fix-bed catalyst, supercritical process

\section{1 はじめに}

食用油脂の水素添加（硬化）反応は, 油脂の分別法, エステル交換反応と並ぶ重要な油脂の改質法の一つで, 油脂を構成する脂肪酸のうち，不飽和脂肪酸の二重結合 にニッケルなどの金属触媒の存在下で水素を付加させる 化学反応を指している。

この反応によって得られた油脂は, 液状油から固形脂 に物性変化することで硬化油と呼ばれ, 硬化油は不飽和 度（ヨウ素価）の減少とともに,

1）酸化安定性, 熱安定性の向上

2) 融点の上昇, 固体脂含量の増加

3) 色相の淡色化

4) 風味変化 (原油からの風味の除去及び低減)

のような改質効果があることから, 油脂への水素添加は, 安定性の向上や可塑性の変化を要求されるショートニン グやマーガリンといった加工油脂製造にとって，必須工 程として発展してきた。

油脂の水素添加についての優れた総説や紹介は以前よ り多数報告されている。しかし，ここ10 年ほどの間,

連絡者：依田 稔
食用油脂の水素添加に関する報告があまり見られなく なってきた。今回, 特集の発刊にあたり食用油脂の水素 添加について, 基礎的なまとめと最近の省力化や生産性 向上に向けた硬化設備の改良, 触媒活性の向上や新たな 水素添加法などの加工技術の進歩について述べてみた い。

\section{2 硬化油の歴史}

硬化油製造の歷史は古く，その製造原理は，今からほ ぼ 100 年ほど前の 19 世紀末から 20 世紀初期にかけてフ ランスの Sabatier \& Senderens（1897〜1905）により研 究がすすめられ，始まりは，有機化合物のニッケル触媒 による水素添加であった。油脂の液相水素添加法として は，初めてイギリスの Normannにより確立された。そ の後, 1906 年には鯨油の硬化油製造が小規模ながら開 始され，さらに，アメリカでも油脂の可塑性油脂製造の 必要性から綿実油を硬化して，1911 年にはProcter＆ Gamble 社からクリスコショートニングの発売へと発展 していっだ。

日本においては, 大正 2 年（1913）に日本リーパ・ブ ラザース社の硬化油製造が行なわれたのが始まりであ り，日本人の手で本格的に工業化されるようになったの 
は，大正 5 年 (1916) のことである2)。ここ最近 10 年 間の日本に打ける硬化油製造の推移は, 1987 年の $289,877 \mathrm{t}$ (内工業用 $16,958 \mathrm{t}$ ) ${ }^{3}$ から 1997 年の $270,531 \mathrm{t}$ (内工業用 9,910 t $)^{4)}$ へと減少傾向を示している。この ことは, 家庭用マーガリンでは消費レベルでの減少と「低 カロリー」ヘルシータイプへの移行も硬化油減少の要因 となっていると思われる。また，業務用のマーガリン， ショートニングに打いては, 最近のパン生産量が横這い 傾向にあることによると思われる。さらに，拍車をかけ たのが安価で大量に使用されていたペルーのアンチョ ビーなどの魚油がエルニーニョの発生に伴う漁獲の不振 による減少で, パーム油やパーム硬化油へと他の油脂へ 変換が図られるにしたがい, 全体的な硬化油生産量が減 少して来たためと考察される。

さらに今後， 21 世紀に向けて，食のへルシー化や卜 ランス酸問題も課題として残るため硬化油としての大き な增加は望めないと思われる。

\section{3 硬化反応}

\section{$3 \cdot 1$ 硬化反応の進行}

油脂の水素添加反応は, 油脂にニッケルなどの金属触 媒を分散させ，その触蝶混合油脂に水素ガスを吹き込む ことにより, 油脂を構成する脂肪酸に存在する二重結合 に水素を付加させる反応である。

油脂の硬化反応は, 3 種類の相が異なった不均一系 (油 脂 液体, 水素 気体, 触媒 固体) での反応が行なわ れ, 硬化反応装置内で行なわれる反応は, 極めて複雑で あり，次のように進行すると考えられている。

(1)水素ガスが油脂中に吹き込まれ，水素の小泡となって 分散し, やがて泡の周囲を取り囲む油脂の薄い膜を通 過して溶解して行く。

(2)油脂に溶解した水素は, 触媒表面周辺へと移動する。

(3)触媒表面へと移動した水素は, 触媒の細孔内にある活 性なニッケル表面に化学的吸着される。

(4)油脂の不飽和脂肪酸基はニッケル表面上で化学的吸着 された水素と不安定な複合体を形成し, 硬化反応及び 異性化反応が行なわれる。

(5)反応した油脂は触媒から離脱し，同時に新しい水素と 油脂が供給される(5) 〜7)。

このように油脂の硬化反応は, 触媒上での水素と油脂 の不飽和脂肪酸基の移動により連続的に行なわれる。硬 化反応の反応条件 (水素圧力, 反応温度, 触媒量, 筧拌 速度）の変化はこの物質移動に影響し, その結果, 反応 速度や選択性, トランス酸の生成といった硬化反応のい ろいろな現象に大きな変化を与える。

\section{$3 \cdot 2$ 硬化反応の機構}

触蝶細孔内の活性のあるニッケル表面では，化学的吸 着された水素（原子状態）と不飽和脂肪酸基とが不安定
な複合体を形成する。この複合体は，非常に高い反応性 があり，不飽和脂肪酸基に水素を与えることで水素添加 反応が進行する。その後両者が離脱してもとの触媒に戻 ることを繰り返すことで硬化反応は進行して行く。

不飽和度の高い脂肪酸を含む油脂 (ヨウ素価の高い) は低い油脂に比べて触媒表面との親和力が強く, 共役シ エン体や活性メチレン基をもった不飽和脂肪酸は，さら に親和性が大きい。その親和力の強さの順番に触媒表面 上で水素との複合体を形成し，水素の授受を受け水素添 加が起こる。すなわち，オレイン酸よりリノール酸が, リノール酸よりリノレン酸がより速く水素添加される。 しかし, 実際の選択的硬化反応においては, 完全に選択 的に水素添加されるのではなく, リノール酸の水素添加 と同時にオレイン酸の水素添加も一部進行し，さらに， 水素添加と同時に部分的な脱水素反応も起こることか ら, 多くの位置異性体や幾何異性体なども生成し, 反応 は必ずしも簡単ではない辛 99)。

$3 \cdot 3$ 選択的硬化反応条件

硬化反応条件には, 次の 4 つのパラメーターにより決 定される(10)。

1）水素ガス圧力

2) 反応温度

3）触媒量

4) 摚抖速度

さらに

5）硬化原料油の性状

6) 触媒の種類

などが上げられ，これらの反応条件を変化させた場合に 硬化反応速度，選択性，トランス酸の生成量が違ってく る。

1）水素压力と選択性

反応油脂全体の水素濃度が上昇すると, 触媒細孔内の 水素濃度も同様に上昇し，不飽和脂肪酸基と水素の反応 中間体はすべて水素添加され，吸着力（反応性）の差に よる中間体の交換は起こりにくくなり，その結果モノエ ンも硬化され，飽和脂肪酸が多量に生成され非選択な反 応が進むことになる。

Table 1 に異なった水素圧力で反応させた時の大豆硬 化油の分析值を示しているが，压力が增すほど飽和脂肪 酸の生成が多くなり，反応がより非選択的反応に向かっ ていることを示している。また逆に，トランス酸の生成 は減少する結果となる。

以上のことから，選択的反応は触媒に対して水素濃度 レベルを減少させることにあることを示している。

2) 反応温度と選択性

反応温度が上昇すると, 反応はより選択的になり, 卜 ランス酸の生成は上昇する。

Table 2 に異なった温度で大豆油を硬化した時の分析 
Table 1 Characteristics of Soybean Oil Hydrogenated under Different Pressures.

\begin{tabular}{c|c|c|ccccc|c}
\hline \multirow{2}{*}{ Sanple } & \multirow{2}{*}{ IV } & \multirow{2}{*}{ MP } & \multicolumn{4}{|c|}{ Fatty acid composition(\%) } & \multirow{2}{*}{ Trans acid content } \\
\cline { 4 - 7 } & & $\left({ }^{\circ} \mathrm{C}\right)$ & C16:0 & C18:0 & C18:1 & C18:2 & others & $(\%)$ \\
\hline $0.5 \mathrm{~kg} / \mathrm{cm}^{2}$ & 75.1 & 31.7 & 10.2 & 5.1 & 77.4 & 5.7 & 1.6 & 47.4 \\
$1.5 \mathrm{~kg} / \mathrm{cm}^{2}$ & 74.2 & 33.9 & 10.8 & 7.4 & 71.6 & 10.1 & 0.1 & 38.6 \\
$4.0 \mathrm{~kg} / \mathrm{cm}^{2}$ & 74.8 & 39.7 & 10.4 & 12.4 & 58.7 & 16.3 & 2.2 & 27.9 \\
\hline
\end{tabular}

Reaction temperature $175^{\circ} \mathrm{C}$, Catalyst $0.02 \% \mathrm{Ni}$, Agitaiton $960 \mathrm{rpm}$

Table 2 Characteristics of Soybean Oil Hydrogenated under Different Temperatures.

\begin{tabular}{c|c|c|ccccc|c}
\hline \multirow{2}{*}{ Sample } & \multirow{2}{*}{ IV } & \multirow{2}{*}{\begin{tabular}{c} 
MP \\
\cline { 3 - 8 }
\end{tabular}} & & \multicolumn{4}{|c|}{ Fatty acid composition(\%) } & \multirow{2}{*}{ Trans acid content } \\
\cline { 4 - 8 } & & & C16:0 & C18:0 & C18:1 & C18:2 & others & $(\%)$ \\
\hline $140^{\circ} \mathrm{C}$ & 73.4 & 36.5 & 10.1 & 7.5 & 68.1 & 12.3 & 2.0 & 33.2 \\
$200^{\circ} \mathrm{C}$ & 72.9 & 33.8 & 10.5 & 4.7 & 73.0 & 10.1 & 1.7 & 43.9 \\
\hline
\end{tabular}

Catalyst $0.02 \% \mathrm{Ni}$, Pressure $2.0 \mathrm{~kg} / \mathrm{cm}^{2}$

值を示してある。高温で反応した場合には，同じヨウ素 価に打いても飽和脂肪酸（ステアリン酸）の生成量は少 なく，トランス酸は多く生成されている。すなわち高温 での反応の方がより選択的反応に向いていることから, 反応温度の上昇は, 触媒細孔内の水素濃度を低下させる ことがあきらかである。

しかしながら, 温度上昇による水素の油脂への溶解度 は上昇することから考えると, 水素濃度レベルは高くな り，選択性は低下するはずであるが，水素濃度の上昇よ りも触媒活性の増大の方が相対的には大きいと考えられ る。つまり, 反応装置での水素ガス供給量がコントロー ルできる場合には, 反応温度の上昇によって反応が加速 され，水素が消費されても水素の供給が少ないため水素 濃度は低く保たれ，選択性は向上し，トランス酸も多く 生成されると考えられる。

3）触媒量と選択性

触媒量の增加は, 油脂中の細孔数を增加させ，限られ た水素量に対して相対的に水素濃度を減少させる。また， 触媒量の増加により反応速度は上昇し, 同時に油脂中の 水素濃度レベルは低下することで, 選択性は向上し, ト ランス酸は多く生成される。この場合においても, 水素 の供給コントロールが必要条件である。

4) 筧拌速度と選択性

摚找速度は油脂への水素の溶解性に影響し, 速くなる
に従い油脂中の水素濃度は上昇するため，選択性は低下 し, トランス酸の生成も抑えられる。逆に摚找速度が遅 くなると水素供給が減少して選択性は向上し, トランス 酸も多く生成される(6).8)。

以上のことをまとめると, 硬化条件は, 触媒の活性能 に対する水素の吸着量で決定される。すなわち選択的硬 化反応条件下では, 水素の吸着量を抑制し, トランス酸 の生成を促して, 飽和酸の生成を抑え, 多不飽和酸を減 少させる。また逆に, 触媒への水素の吸着量を增加させ ると非選択的な硬化反応となり，トランス酸の生成も少 なくなる (Table 3)。

\section{4 原料油脂}

原料油脂中に存在する不純物には, 硬化反応時の触媒 に対して, その活性を低下させ，異性体を多く生成させ る触媒毒と呼ばれる物質を含んでいる。

したがって，硬化反応を順調に行なうためには，これ ら触媒毒となる不純物を十分に除去しなければならな い。

原料油脂中に含まれる不純物には，イオウ化合物，リ ン脂質, 不けん化物, 過酸化物, 石战分, 遊離脂肪酸, タンパク質，炭水化物，水分などがあげられる。

これらの中でイオウ化合物は, 代表的な触媒毒で, 被 毒作用が最も強く, ニッケル触媒と直ちに反応して, 油

Table 3 Effects of Process Conditions on Hydrogenation.

\begin{tabular}{lcccc}
\hline $\begin{array}{c}\text { Reaction parameters } \\
\text { (Increase) }\end{array}$ & $\begin{array}{l}\text { Hydrogen } \\
\text { concentration }\end{array}$ & $\begin{array}{l}\text { Reaction } \\
\text { rate }\end{array}$ & Selectivilty & $\begin{array}{c}\text { Trans acid } \\
\text { formation }\end{array}$ \\
\hline Pressure & + & + & - & - \\
Temperature & - & + & + & + \\
Catalyst concentration & - & + & + & + \\
Agitation & + & + & - & - \\
\hline
\end{tabular}


脂中のイオウ $1 \mathrm{ppm}$ で 0.004\%（40 ppm）のニッケルが 活性を失ってしまう。また, リン脂質もイオウほどでは ないが強い被毒作用がある。これは, 直接ニッケルと化 学反応を起こすのではなく, 触媒表面の細孔を塞いで脂 肪酸基の出入りを妨害することにより硬化反応の進行を 抑えてしまう。遊離脂肪酸は, 含量が多いとニッケル石 畧を作り, リン脂質と同様のメカニズムで触媒を不活性 化する。さらに, 石畧分, 過酸化物, 炭水化物なども触 媒の活性を低下させる。通常, 油脂中の石唫分は25 ppm 以下が望ましいといわれている。さらに, 油脂中 の微量水分は厳密に言えば触媒毒ではないが, 油脂の加 水分解による遊離脂肪酸を生成する原因となるので注意 する必要がある。その他, 植物油糧では殺虫剤由来と思 われる有機塩素系農薬も触媒毒と成り得るので注意を要 する ${ }^{11) \sim 13)}$

以上のことから, 油脂中にはこれら多種の原料由来に よる触媒毒や不純物が存在することから, 触媒毒除去の ためにも必要に応じて脱ガム, 脱酸, 脱色の前処理を行 なうことが一般的であり，精製した油脂を硬化反応用に 用いるのが望まし(14).15)。

\section{5 反応装置}

硬化反応は，油脂と水素ガスを触媒上に集合させるこ とにより開始される。このため，工業的にも硬化を行な う装置は，油脂中で水素ガスが触媒表面にいかに効率良 く接触して反応を促進することができるかを条件設計と して，いろいろな形式の反応装置が考案されて来た。反 応装置は，大別するとバッチ式（回分式）反応装置と連 続式反応装置に分けられる。一般的に食用硬化油は各社 とも製品の融点, ヨウ素価, 固体脂含量等の品質規格が 多様であること，選択硬化反応を行なう場合には硬化条
件を厳密に管理できることから，バッチ式装置が主体を 占めて来た。

ここでは，一般的なバッチ式反応装置に含まれるデッ ドエンド反応装置と油循環式反応装置から述べてみる。

○デットエンド反応装置

Fig. 1 に示すように，やや縦型の円筒形反応槽（オー トクレイブ）の頂部には筧拌用駆動装置があり，槽内に 二段以上のタービン型の擋拌羽根を有し，内壁にそって 過熱用及び冷却用コイルが巻かれている。さらに, 外部 からは真空発生装置との連結パイプライン, 原料油の受 入れラインと途中に触媒混合タンクからのラインと接続 したライン, 反応終了後の油の払出しライン, 最後に低 部からは水素ガスの吹込みパイプが接続している装置で ある。

反応は低部から吹込まれた水素ガスが細かな泡となっ て油脂中に分散すると，さらに筧拌羽根の強力な擋拌に よって細かく分散され油脂, 水素ガス, 触媒の接触効率 を高められて硬化反応が進行する。未反応の水素ガスは, 反応槽の上部の寽間（ヘッドスペース）へ溜まるが，挡 找力により再び油脂中に巻込まれ油脂中に分散して行 $<$ 。

反応初期段階では, 反応が活発であるため水素ガスの 消費速度は速く, 油脂中に吹き込まれた水素ガスは, 全 て吸収されへッドスペースにはほとんど到達しない。し たがって，ヘッドスペースの水素圧は低く保たれ，水素 ガスの供給圧力とへッドスペースの压力差は大きくな り，大量の水素ガスが供給される。

しかし, 硬化反応が進み, 反応速度が遅くなると水素 ガスの吸收が低下し，多くの水素ガスがへッドスペース まで到達するようになる。そのようになるとへッドス ペース内の压力が上昇し, 水素ガス供給庄力との差は小

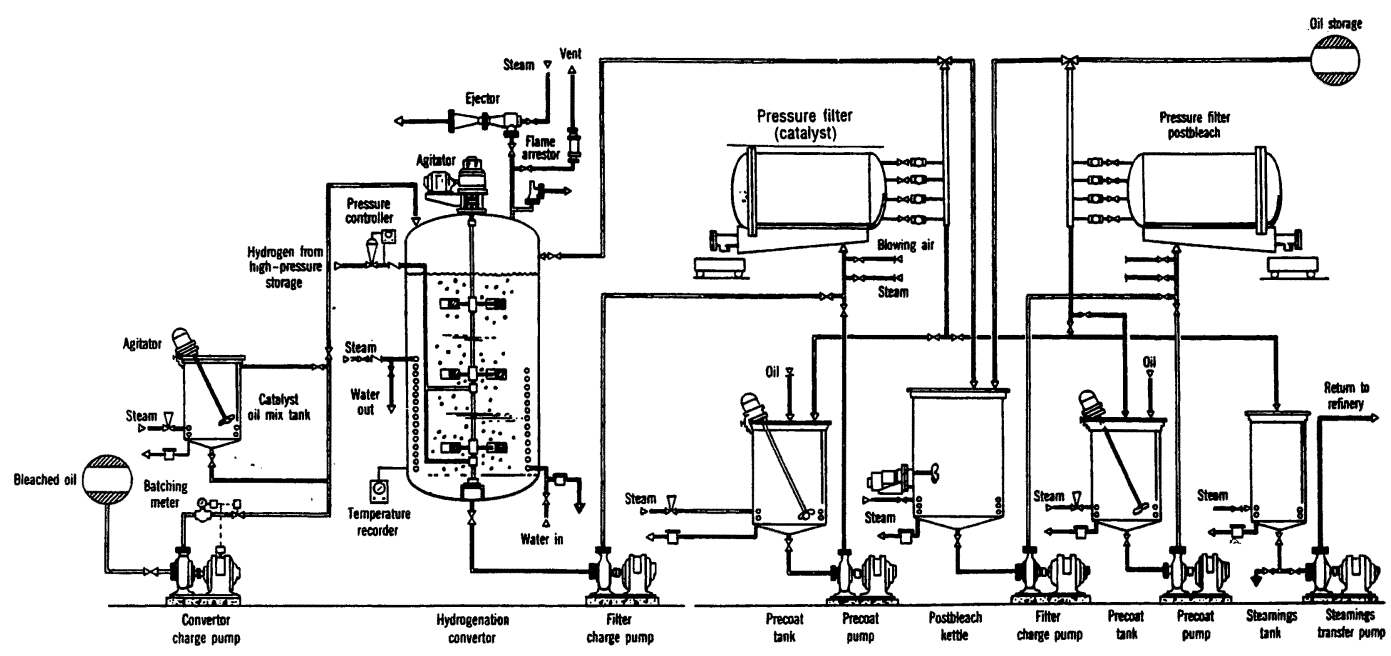

Fig. 1 Dead-end Reactor. 


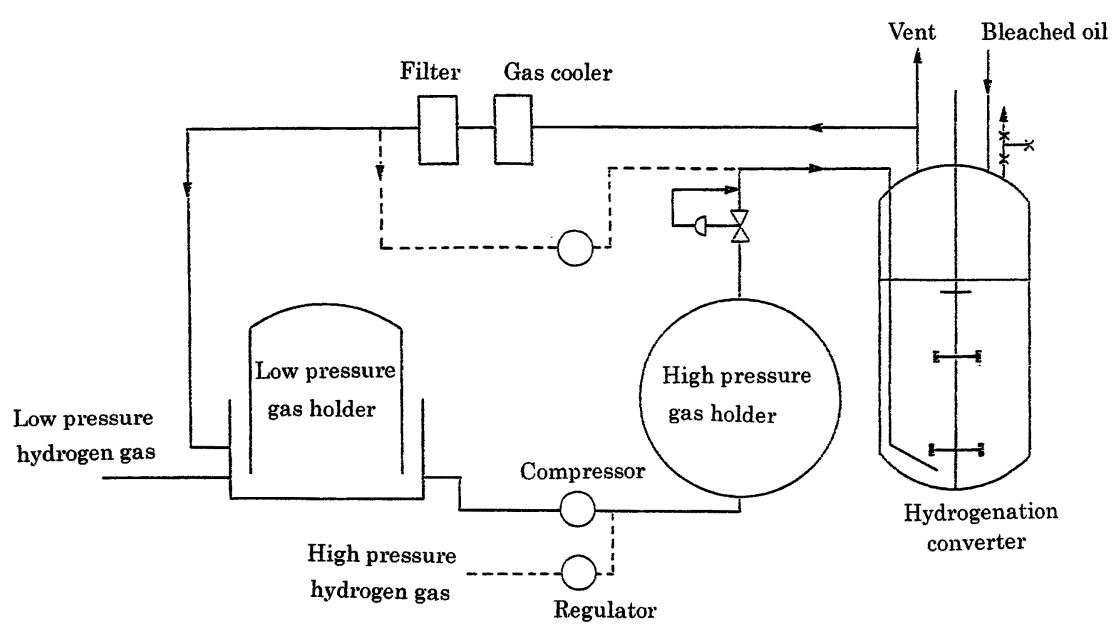

Fig. 2 Hydrogen Gas Circulation Reactor.

さくなる。その結果, 反応槽への水素ガスの供給量は減 少する。反応速度の低下が同時に水素ガス供給量の減少 になってしまう欠点を有している。

その後の改善により，ガス循環式の反応装置が開発さ れた。Fig. 2 に示すように，反応中にへッドスペース に溜まった水素ガスは反応槽より取り出され, 冷却及び 洗浄されて反応後の揮発性物質（水分, 分解物など）を 除去された後，コンプレッサーで外部からの供給水素圧 力まで压力を高められ，再び反応槽へ吹込まれる。

このガス循環式反応装置では，硬化速度が低下してき ても強制的にガスを送り込めるため, 急激に反応が減速 してしまう傾向は少なく，硬化時間の短縮にもなる。ま た油脂中の水素ガス濃度をある程度一定に保つことが可 能なことから, 選択的な条件を維持しやすいという長所 をそなえている(5).1(i)。

\section{○油循環式反応装置}

この装置は, BUSS System（スイス）が有名であり, 簡単な装置構造を Fig. 3 に示す。

この装置での反応は，触媒を分散させ所定の温度まで 加熱された油脂が反応槽の低部から送油ポンプでサク ションされ, 温度コントロールを目的とする熱交換器を 通過後, 反応槽内頭部の自己吸収式の混合ノズルから再 び吹き出され，水素ガスを強制的にノズル内に吸い込ん で触媒混合油脂と強く混ぜ合わせることにより進行す る。ここで硬化された油は, 再び反応槽へ戻り, 反応に 使用されなかった水素ガスも反応槽上部のへッドスペー スへ浮上し再度反応に使用される。

ノズル内の油と水素ガスの混合は極めて効率的であ り, 接触面積は通常の擋找式反応装置で約 2 倍, または, デッドエンドタイプの反応槽の 2 - 3 倍といわれている。 そのため, 通常の反応装置に比べ反応時間が短縮される
結果となる ${ }^{17)}$ 。また最近，日本においてもべンチュリー ノズルによる噴霧方式を採用した循環式反応装置での硬 化実験の報告もなされている ${ }^{18)}$ 。

\section{○連続式硬化反応装置}

より効率的な連続式硬化反応を目指した検討は，固定 床流通式反応器や高活性貴金属触媒やニッケル触媒の開 発と，さらに硬化原料油の精製度の向上による触媒毒成 分除去の進歩をもたらし，固定床触媒 (Fixed-Bed Catalyst）を利用することで連続での硬化反応が可能に なった。それにより，硬化反応後の油からは触媒を除去 することが省略され，さらに高い反応性と省エネルギー 化を達成することが出来た。このことから，固定床触媒

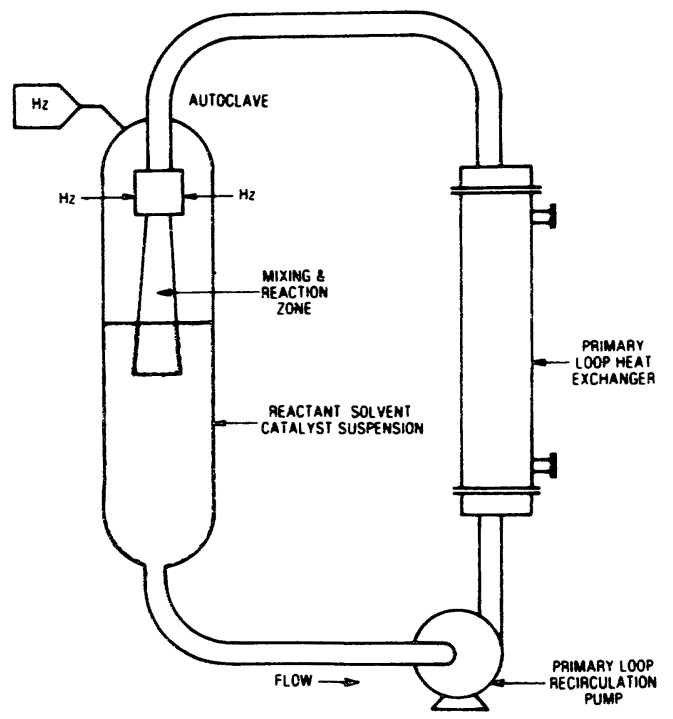

Fig. 3 Buss Loop Reactor. 
利用の連続式硬化反応装置がしだいに利用し始められて いる。

従来からの連続硬化反応装置としては, Lurgi 式, King-Dravo 式, Procter \& Gamble 式は良く知られてい る装置であるが, 最近の研究では触媒充填ディスク回転 型反応装置などの多くの開発も試みられているようであ る $^{19)}$ 。

\section{装置上の改良}

硬化反応後の油と次の硬化原料油との熱交換すること で，ユーティリティの削減と同時に加熱・冷却時間を短 縮することで一日の生産量（生産ロット回数：平均 12 回から 15 回) の増加も成し遂げられている ${ }^{11)}$ 。ライン 中の触媒仕込み用スラリータンクでは, 触媒残留固形物 の完全払出しを目的としたスラリータンク底の開閉用バ ルブに Seat Valveを採用する工夫もされている(1)。硬 化終点決定では, ヨウ素価測定に代わるインライン屈折 計測定での検討もなされ, 今では触媒を含む反応油でヨ ウ素価 1.0 の精度での測定も可能になりつつあ る(1).20)。また, 硬化反応を終了した油から効率良く触媒 を除去する方法”1)など装置周辺での改良もなされてい る。

\section{6 触 媒}

油脂の硬化用触媒に使用される可能性のあるものは, 金属のニッケル，コバルト，銅と貴金属のパラジウム， 白金，ロジウム等があり，酸化物としては比較的高温で の水素化反応する銅クロム酸化物または酸化銅がある。 実用上（活性, 選択性, 寿命, 価格) で圧倒的に多く使 用されている触媒はニッケル触媒である。またここ数年 の研究では，バッチ式から連続式（固定床）への技術進 歩につれて，貴金属触媒が独特な選択特性を持っている ことからニッケル触媒に代わって使われ始めてい る(2) - 21)。

\section{$6 \cdot 1$ ニッケル触媒}

現在一般に使用されているニッケル触媒は，大きく還 元ニッケル触媒，ギ酸ニッケル触媒，ラネーニッケル触 媒に分類される。

\section{還元ニッケル触媒}

現在, 油脂の硬化反応に使用されるニッケル触媒の大 部分は, この還元ニッケルタイプの触媒であり, 還元ニッ ケル触媒は, 硫酸ニッケルなど酸性の水溶性のニッケル 塩をアルカリにより担体上に塩基性炭酸ニッケルとして 沈殿させ，この炭酸ニッケルを水素気流中で還元して金 属ニッケルへ転換させた触媒である。このタイプの触媒 は，最終工程において還元反応により触媒活性を有する 金属ニッケルとすることから，還元ニッケル触媒と呼ば れている。

還元品（金属ニッケル 担体）は，非常に酸化され易
いため, 還元後は窒素需囲気中でこの粉末を極度硬化油 に分散させフレーク状や粒状に固化して保存する。この ように硬化油（極度）を保護物質とした触媒が最も一般 的であるが，還元した粉末の表面だけを酸化させて安定 化した粉末状の安定化二ッケル触媒も製造されており, 保護用の極度硬化油の混入を嫌う微水添液体油の製造な どに使用される。この触媒の活性化には比較的高温（一 般には $160^{\circ} \mathrm{C}$ 以上）が必要である。

ギ酸ニッケル触媒

ギ酸ニッケル触媒は，担体上の炭酸ニッケルをギ酸と 反応させてギ酸ニッケルを作り，さらに熱分解させて金 属ニッケルを生成させた触媒である。

この触媒は, 還元ニッケル触媒より低温活性, 選択性 が優れているが，製造上触媒粒子がきわめて微細になる ため沪過性が悪く，工業的にはあまり多くは使用されて いないのが現状である。

\section{ラネーニッケル触媒}

ラネーニッケル触媒は，ニッケル触媒の中に含まれる が，ニッケルとアルミニウムの合金粉末からアルミニウ ムを塩基で溶出することによって，骨格状のニッケルを 水中に形成するために，貴金属に匹敵する低温活性を持 つことで他のニッケル触媒と区別される。

ラネーニッケル触媒を油脂の分野で使用するのは $100^{\circ} \mathrm{C}$ 以下の低温反応でトランス酸を減らすことがねら いであるが，現在ではほとんど使用されていない。

\section{$6 \cdot 2$ 貴金属触媒}

白金, パラジゥム, ロジウム, ルテニウムなどは貴金 属として特徴のある集団で, 他の触媒では考えられない 低濃度での活性を示し, 低温活性, 耐毒性, 酎酸性, 耐 熱性にも優れている。貴金属はそれ自身高価なものであ るが, 使用濃度を少なく, 回収率を高くし, 使用中の活 性低下に問題がなければ，他の金属触媒と対抗できると いわれている。

最近, 油脂の硬化では, 極めて清浄な原料油を得るこ とが出きれば低温で反応できるとのことで, 粒状の貴金 属触媒を固定床に設置し連続水素添加する検討も行なわ れており，将来的な発展に興味が持たれる25)。

\section{3 銅 触 媒}

銅系の水素化触媒としては, 銅 クロム酸化物触媒ま たは銅、クロム、ンガン酸化物触媒が代表な油脂硬化 用触媒であり，これら銅系の触媒は，ポリエンに対して 優れた選択性を示す。しかし，活性が弱いため 2 3\% の使用量を必要とし, 反応速度が遅いことなどの問題が ある。また, 油脂中に銅が溶出し劣化の原因となること を防ぐため, 硬化油の後処理 (硬化後の精製) にも他の 触媒使用時より一層の注意が要求される。このような欠 点から現在では油脂の硬化にはあまり使われなくなって きている。主な用途としては，界面活性剈に利用される 


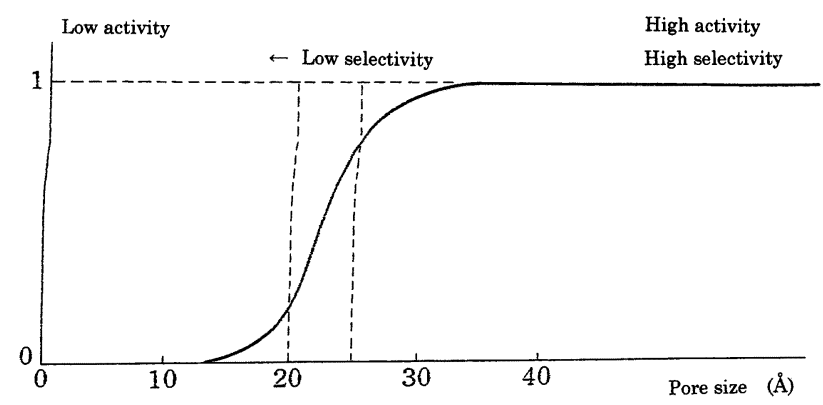

Fig. 4 Effect of Pore Size on Catalyst Selectivity and Activity.

高級アルコール製造用触媒として利用されている。

\section{$6 \cdot 4$ 触媒の構造と活性}

触媒の構造に関して活性と関連するものは，担体の粒 径（触媒の粒径）と細孔径の大きさである。

硬化反応は，触媒の細孔表面で行なわれるが，触媒の 粒径が小さいほど単位重量あたりの表面積は大きくな り，細孔数も多くなる。このように表面積が大きくなれ ばトリグリセリド分子が触媒と接触する機会が増え, そ の結果，反応は迅速に進行する。これは高活性であるこ とを意味する。Coenenは触媒粒子の大きさは顕微鏡観 察の結果 1 30 ミクロンであるとし，この範囲において 触媒の活性は触媒粒径の逆数に比例すると述べている。

しかし，触媒粒子の大きさを小さくすれば活性はよく なるが, 粒子が小さくなり過ぎて沪過面を密に覆ってし まい，沃過性が悪化することになる。したがって，粒子 の大きさは活性と沪過性とのバランスによって決定され るものであり，この矛盾点を解決することは触媒メ一 カーの技術の見せ所であろう。

もう一つ触媒の活性に影響を与えるものは, 細孔の広 さである。トリグリセリド分子は細孔内に浸入し触媒表 面で水素と結合するが，もし，細孔内の広さがトリグリ セリド分子の大きさより小さい場合にはトリグリセリド 分子は触媒の細孔内に浸入することができず反応は進行 しない。同じく Coenenの実験によると細孔の広さが 25 Aより小さくなると硬化反応は全く進行しなくなり, それより大きい細孔径の範囲では細孔が大きくなるほど 活性は高くなっている。これは細孔の広さが大きいほど トリグリセリド分子はスムースに細孔内に出入りできる ようになり，その結果硬化反応は早く進行する。

また, 細孔構造は選択性とも密接関係があり, 細孔径 の大きさはトリグリセリド分子の細孔内への浸入と反応 後の細孔内からの離脱の容易さに大きく影響し, 細孔径 が充分大きい場合には分子が容易に出入りできるため, 一つの分子に対して一度しか反応が起こらず，そのため 反応は選択的になる。また逆に, 狭いと一度入った分子 が出にくくなるため何回も反応してしまい飽和酸まで進
行してしまうと考えられている26)。

細孔径の大きさと選択性の関係を Fig. 4 に示す。ま た, 触媒構造（粒径と細孔径）と選択性及び沪過性につ いて Fig. 5 に示す。

最近の触媒の進歩で注目されることは，ニッケル触媒 の触媒表面積の増大技術で活性の増加により触媒毒に対 する耐性も増大させて，20 年間で触媒使用量を半減さ せるまでに至っている11) (Table 4)。

また, 別の報告によるとニッケル触媒の表面積増大に よって，その使用量を 1920 年の $0.1 \%$ から 1990 年の $0.025 \%$ まで削減できたとしている25)。

\section{7 廃触媒・廃白土処理}

硬化反応後の硬化油は, 触媒除去処理, 脱色処理, 脱

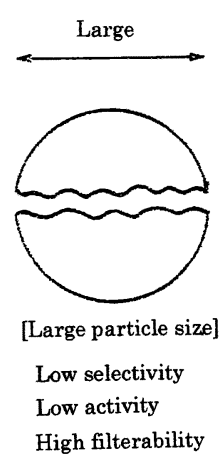

Small

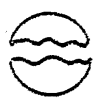

[Small particle size]

High selectivity

High activity

Low filterability

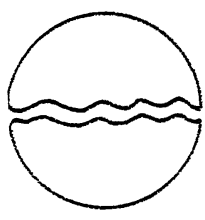

[Narrow pore size]

Low selectivity Low activity

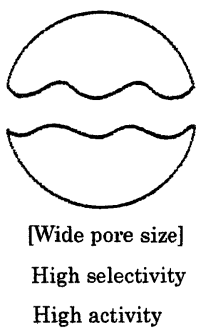

Fig. 5 Particle Size and Pore Size of Catalyst. 
Table 4 Poisoning Effect of Thioglycerol and Cysteine versus Catalyst Nickel Surface Area.

\begin{tabular}{cccc}
\hline Year & $\begin{array}{c}\text { Ni surface area } \\
\left(\mathrm{M}^{2} / \mathrm{g} \mathrm{Ni}\right)\end{array}$ & $\begin{array}{c}\text { Thioglycerol } \\
(\mathrm{ppm} \mathrm{Ni} / \mathrm{ppm} \mathrm{S})\end{array}$ & $\begin{array}{c}\text { Cysteine } \\
(\mathrm{ppm} \mathrm{Ni} / \mathrm{ppm} \mathrm{S})\end{array}$ \\
\hline $1970 \mathrm{a}$ & 70 & 32 & 48 \\
1988 & 12 & 17 & 22 \\
1990 & 160 & 14 & 15 \\
1993 & 180 & 10 & 13 \\
\hline
\end{tabular}

a:Poisoning factor mean value $=0.004 \% \mathrm{Ni} / \mathrm{ppm} \mathrm{S}=40 \mathrm{ppm} \mathrm{Ni} / \mathrm{ppm} \mathrm{S}$

臭処理の工程を通過して最終の食用硬化油となる。その 工程中で, 触媒除去処理工程からはニッケルを含んだ廃 触媒が排出される。脱色処理工程からは色素, その他の 不純物及び触媒除去処理で除去しきれない微量のニッケ 儿分を含む廃白土が排出される。これら使用済加工助剤 は，加工油脂メーカーにとっては不用物である。

これら廃触媒, 廃白土は, 現在は専門の業者に引き取 られ処理されている。かつては廃触媒中のニッケルを回 収して再生触媒としてリサイクルされていたが，最近で は，ほとんど再生触媒とされることはなく，主にステン レス鋼の合金用金属として再利用されている。また同様 に, 微量のニッケルを含んだ廃白土も廃触媒と混合して ステンレス鋼用の金属として再利用されていたが，産業 廃棄物として処理することを要求されるようになって来 ている。なお，精製後の廃白土は，そのままセメント原 料の配合用や肥料への応用にも注目されているようであ る(7)。

これら廃触媒や廃白土は産業廃棄物として扱われるこ とではなく，より多くの再利用の道が開かれることを期 待したい。

\section{8 新しい水素添加方法}

最後に，これまで述べてきた水素添加反応とは異なる 新しい動き（試み）について挙げてみる。

\section{$8 \cdot 1$ 化学的水素添加}

通常の水素ガスを使う水素添加反応とは別に，新しい 手法による反応も試みられている。

それは, 従来の水素ガスを使用する代わりに水素供与 体（Hydrogen-Donor）としてギ酸ナトリウムを使用す る方法で, 油脂 水一触媒の 3 成分から成る硬化反応で ある。ギ酸ナトリウム水溶液一油脂一触媒を擋拌乳化さ

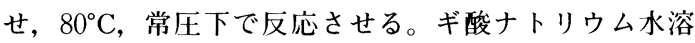
液からは解離した水素が油脂と水溶液の界面上の触媒に 移動し，水素添加反応が行なわれる方法で，まだ実験室 段階での試みではあるが良好な選択性と反応性が得られ ている。安全性及び作業性から見て興味ある硬化反応で ある28)

同様に水素ガスを直接使用しない反応としては，半導 体光触媒を用いる水素添加方法がある。白金，銀，パラ ジウムを酸化チタンに担持した触媒を使って，水及び／
又はアルコールを水素発生源とし，その溶液中で油脂ま たは不飽和脂肪酸に光を照射して水素を添加させる。室 温，常压下でも反応が進行するので，加熱や水素ガス供 給を必要としないメリットがあるとの報告がされてい る $^{29)}$ 。

\section{$8 \cdot 2$ 超臨界下での水素添加}

触媒に貴金属やニッケルの固定床触媒を利用し，溶媒 に二酸化炭素，プロパンなどを用いて，水素と油脂ある いは不飽和脂肪酸の混合物を超臨界または近臨界状態で 硬化反応を行なう試みもなされている 30 ..317。反応速度は 接触反応の 1000 倍で，トランス酸生成の少ないより選 択性の高い硬化反応が可能と報告されている ${ }^{20) .25) 。 ~}$

\section{$8 \cdot 3$ 生物学的水素添加}

牛，羊のような反剓動物の第一胃 (ルーメン) 中では, 油脂は生体内で微生物によって水素添加され ${ }^{32)}$, 不飽和 脂肪酸から飽和脂肪酸やトランス酸が生成される。この 結果, 牛乳, バター，牛肉などの油脂中にはトランス酸 が最高で 7〜8\% 含まれている。これを応用してルーメ ン細菌またはその細菌の抽出物を用いた油脂から誘導さ れた遊離不飽和脂肪酸を選択的に飽和化するバイオ利用 による水素添加の報告もある ${ }^{33)}$ 。

\section{4 そ 他}

ニッケル触媒を用いる通常の硬化反応に対して磁場を かけることによる選択水添の検討も報告されている ${ }^{34)}$ 。 また，水素添加反応に及ぼす不活性ガスの影響(3.) や水素 眝蔵合金使用によるトランス酸含量の少ない水素添加食 用油の製造 ${ }^{36)}$ な゙の新しい水添法や効率の良い反応と 言った特許または報告もみられるが，実用にはさらなる 検討が必要と思われる。

\section{9 あとがき}

今後の硬化油の課題を考えるとき，第一に想起される のはトランス酸の代謝問題である。現在では，ゼロトラ ンスを目指す製品では極度硬化，分別，エステル交換を 組み合わせることによってトランス酸を含まない製品の 実現が可能となっている。しかし，従来の方法にとらわ れない新しい発想での硬化反応を検討することも必要で あろう。

なお、最近 10 年ほどの間、硬化反忘における研究報 告も少なく、硬化に関する研究も少なくなってきたよう 
に感じられる。最新の先端的な研究開発が特に待たれる 所である。

(受付：1999年 5 月 21 日, 受理：1999年 7 月 16 日)

\section{文献}

1) D. Swern, “BAILEY'S INDASTRIAL OIL AND FAT PRODUCTS”, Vol. 2, 4 th Ed., Wiley-Interscince, New York (1982), P.2.

2) “日本マーガリン工業史”第二巻 全日本マーガリ ン協会 (1977).

3) “油脂産業年鑑” 1988 年 8 月増刊 油脂.

4) “油脂産業年鑑” 1998 年 8 月増刊 油脂.

5) R.R. Allen, J. Am. Oil Chem. Soc., 58, 166 (1981).

6) 伊東耕二, 油脂, 40, 62 (1987).

7) 村瀬行信, 油化学, 28, 689 (1979).

8) 安田耕作, 油化学, 36, 213 (1987).

9) 伊東耕二, 油脂, 40, 84 (1987).

10) D. Swern, “BAILEY'S INDASTRIAL OIL AND FAT PRODUCTS”, Vol. 2, 4 th Ed., Wiley-Interscince, New York (1982), p.14.

11) R.C. Hastert, INFORM., 8, 85 (1997).

12) 伊東耕二, 油脂, 41, 62 (1988).

13) 伊東耕二, 油脂, 41, 76 (1988).

14) 安田耕作, 油化学, 36, 145 (1987).

15) 前橋和友, 油化学, 19, 552 (1970).

16) 伊東耕二, 油脂, 41, 94 (1988).

17) 伊東耕二, 油脂, 41, 66 (1988).
18）武谷宏二, 川成真実, 他, 日本食品科学工学会誌, 42 (4), 237 (1995).

19) Jonas Edvardsson et al, J. Am. Oil Chem. Soc., 71, 235 (1994).

20) R.C. Hastert, Lipid Technology., 10, 101 (1998).

21) 中岡 敏, 他, 公開特許, 平 8-170092.

22) 伊東耕二, 油脂, 40, 89 (1987).

23) 中森一義, 油化学, 19, 556 (1970).

24）触媒工業協会技術委員会編, “触媒の話”化学工業 日報社 (1997).

25) K. Berger, INFORM., 9, 447 (1998).

26) 伊東耕二, 油脂, 40, 82 (1987).

27) 吉富和彦, 日本油化学会誌, 46, 450 (1997).

28) N. Mateja et al., J. Am. Oil Chem. Soc., 75, 629 (1998).

29) 傳 慶一，公開特許，平 9-3481.

30) トーマス・タッケ, 他, 公開特許, 平 9-509440.

31）ヘルロード・マグナス，他，公開特許，平 10505367 .

32）新日本新書, “牛はどうやって草からミルクをつく るのか”小野寺良次, 新日本出版社 (1990).

33）松永 是, 鈴木一昭, 澤 完司, 松本 涉, 公開 特許, 平 1-95794.

34) Aage Jart, J. Am. Oil Chem. Soc., 74, 615 (1997).

35) 武谷宏二, 川成真実, 他, 日本食品科学工学会誌, 42, 410 (1995).

36) 武谷宏二, 川成真実, 他, 日本食品科学工学会誌, 43, 502 (1996). 


\section{[総説 $]$}

して発展してきた。

基礎的な水素添加の内容について概説し，さらに，最近の水素添加法として，固定床触媒利用による連続式硬 化や超臨界での硬化などの新しい硬化方法の開発，それに伴なうニッケル触媒，貴金属触媒の進歩や装置周辺で の改良の動きなどを含めながら概説する。

（連絡者：依田 稔) Vol.48, No.10，1141（1999）
[総説 $]$

[総説 $]$

\section{油脂のエステル交換}

松 本 渉

旭電化工業株式会社基礎研究所

（テ 116-8553 東京都荒川区東尾久 7-2-35）

エステル交換は油脂加工における基本技術の一つであり，油脂産業において広く企業化がなされている。この プロセスはトリアシルグリセリン分子内および分子間での脂肪酸残基の再編成をおこなうものであり，油脂の物 理的性質を改良するものである。最近では酵素を用いたエステル交換が開発され選択的な反応が可能になってき ている。本総説はエステル交換の概要を示すとともに最近の技術の進展を紹介した。

（連絡者：松本 涉) Vol.48, No.10, 1151 (1999)

\section{大豆レシチンの製造と利用 \\ 園 良 治 \\ 辻製油株式会社 研究開発室 \\ （† 515-2314 三重県一志郡嬉野町新屋庄 565-1）}

大豆レシチンは，食品工業分野における重要な界面活性剤であり，大豆から抽出した原油に加水し，分離した ガム質を乾燥することにより得られる。この総説では, 先ず品質の良いレシチンを得るために重要な問題点と, 筆者らで実用化した粗レシチンの直接沪過法による新規な精製法について紹介し，近年開発され市販されている 脱脂レシチン，分別レシチン，酵素分解レシチン，水素添加およびヒドロキシル化等の化学修飾レシチンの製造 法と特徴についても紹介した。これらの新規な製造法によって得られる生理機能に優れたレシチンが, 食品分野 のみならず医薬・化粧品分野へも発展していくことを期待する。

（連絡者：園 良治）Vol.48, No.10, 1161 (1999) 